\title{
Institutional Reform in Transition Economies: How Far Have They Come?
}

Beatrice Weder 


\title{
IMF Working Paper
}

\author{
Research Department
}

Institutional Reform in Transition Economies: How Far Have They Come?

Prepared by Beatrice Weder ${ }^{1}$

Authorized for distribution by Tamim Bayoumi

August 2001

\begin{abstract}
The views expressed in this Working Paper are those of the author(s) and do not necessarily represent those of the IMF or IMF policy. Working Papers describe research in progress by the author(s) and are published to elicit comments and to further debate.
\end{abstract}

This paper examines how institutional conditions in transition economies compare with those in the rest of the world using various indicators of governance. The focus is on the countries in Central and Eastern Europe and the former Soviet Union but, when possible, transition countries, in Asia and Africa are also considered. The main findings are that transition economies, as a group, are no longer distinguishable from other economies, but at the same time, there are large differences in institutional performance within the group of transition economies. A formal cluster analysis is conducted in order to map transition economies into homogeneous groupings of countries. The results of this analysis highlight that transition economies are found at all clusters (from best to worst institutional performers) and also that a group of five countries, all of which are EU accession countries, appear to have "graduated": when taking into account their level of income, their institutional conditions are no longer distinguishable from those in the most advanced industrialized countries.

JEL Classification Numbers:P26, 017, 057

Keywords: Institutions, transition economies

Author's E-Mail Address: Beatrice.Weder@unibas.ch

\footnotetext{
' Department of Economics, University of Basle, Switzerland. Tel: +41 61 2673367, Fax: +41 6126733 33. For helpful comments I would like to thank Tamim Bayoumi, Mark DeBroeck, Oleh Harvylyshyn, and Peter Sturm. This paper was originally prepared as a background paper for the Fall 2000 World Economic Outlook of the International Monetary Fund.
} 
I. Introduction

A. Indicators of Institutional Performance and Differences Within

Transition Countries. .5

B. Are Transition Economies Different from the Rest of the World?

Results from Cross-Country Estimates of Institutional Conditions........................7

C. Mapping Ex-Transition Economies into New Clusters

II. Conclusions.

Tables

1. Are Transition Economies Different? Cross-Country Evidence on Institutions and Transition Economies OLS Estimates, Various Dependent Variables, 1997 .........9

2. FSU and CEE in Cross-Country Comparisons OLS Estimates, Various Dependent Variables, 1997.

3. Are Accession Countries Different? Cross-Country Evidence OLS Estimates, Various Dependent Variables, 1997

4. Results of K-Means Cluster Analysis, Clusters based on Six PP Indicators

5. Results of K-Means Cluster Analysis, Clusters based on Six PP Indicators (without controlling for differences in GDP per capita).

Figures

1. The Reform Gap: Deviation of PP Overall Average Institutional Quality (1997) from the Mean of Industrialized Countries

2. Time Series Evidence on Bureaucratic Performance by Country Groups

Mean Bureaucratic Quality (NC), 1989-1997

3. Actual-Predicted Overall Institutional Quality

Appendix Tables

1. Countries Included in Transition Dummies and Country Coverage of the

Three Main Data Sets, PSS, PP, EBRD.

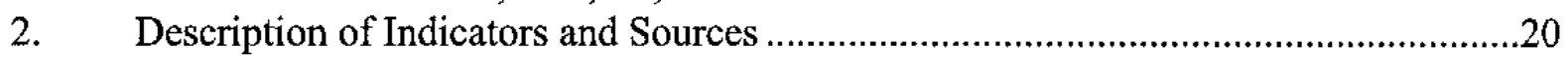

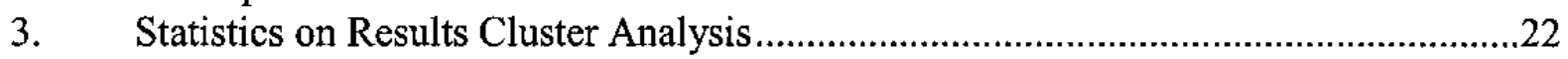

Appendix Figure

1. Goodness of Classification and Number of Clusters

References 


\section{INTRODUCTION}

The label "transition economies" is by now part of our regular vocabulary. Yet, the group of countries that share this label seem to have become increasingly diverse and their commonalties are increasingly historical. After all, the transition process is by now about a decade old. The countries that emerged from the former Soviet Union have been in transition for eight to nine years and Eastern European countries started transiting even earlier. The Asian's transition is more difficult to date since there are some countries that have only started transforming their economies and others that arguably have been doing so for a much longer time than the last decade. At any rate, about 10 years after the breakup of the former Soviet Union it seems natural to ask whether the transition label is still warranted or whether for some countries the transition is over and, for the others, how far their reforms have come. There are already a number of recent papers that address this question, but they mainly focus on the macroeconomic dimension and try to settle some of the early debates (such as the impact of inflation and stabilization, the choice of exchange rate regime, big bang versus gradualist reforms etc. $)^{2}$

The aim of this paper is to take stock of the institutional and legal dimensions of the reform process. It does this by asking three questions: How do transition economies compare among themselves in terms of their institutional performance? How do they compare with the rest of the world? And: How would a more appropriate grouping of transition economies look like? To answer the first question a number of indicators of institutional performance are analyzed. To answer the second question, I run regressions that test whether institutional conditions are significantly different in transition economies from the rest of the world. To answer to the third question I conduct a formal cluster analysis.

The paper indicates that (i) transition economies are very diverse in terms of their institutional conditions and (ii) that transition economies as a group are no longer distinguishable from other economies. Yet there are groups of countries that are very similar among themselves and dissimilar from the others. For instance, the EU accession countries as a group have clearly better institutional conditions than the countries of the FSU. In fact, one finding of the paper is that (according to some measures) institutional conditions in some EU accession countries are not significantly different from those of industrialized countries. A new mapping of ex-transition economies is provided by a clusters analysis in which I classify about 150 countries into homogenous groups taking into account six factor that reflect institutional conditions. We find transition economies in all clusters.

The quantitative assessment of institutional performance conducted in this paper is feasible only because a number of indicators of institutional quality have become available recently. For instance, a world wide private sector survey, carried out for the World Development Report (1997), provided indicators of firms' perceptions about issues such as the predictability of rule making, property rights enforcement or reliability of the judiciary. Firms

${ }^{2}$ See e.g. Fischer and Sahay (2000), Wyplosz (1999), or Berg, Borensztein, Sahay, and Zettelmeyer (1999). 
that sell country risk assessments have been holding experts' survey on issues such as the quality of the bureaucracy, rule of law and corruption. Finally, researchers have aggregated indicators from different sources into summary indicators. This paper uses data from all these sources to compile a comprehensive picture of institutional conditions.

At the outset, it is important to clarify the definition of "institutional conditions." The underlying concept is that a market economy can only operate if there are certain rules of the game and, in particular, that property and contract rights have to be defined and there have to be mechanisms that will credibly enforce them. A well working institutional framework guarantees these rights by enforcing them against violation by third parties as well as by the state. ${ }^{3}$ For instance, corruption, discretionary action of bureaucrats, unpredictable changes in rules and policies, unreliable judiciaries are all means by which the state can de facto expropriate private agents.

The indicators used in this paper addresses these issues, i.e. they map out the quality of the institutional and legal infrastructure for private sector development. Several indicators directly reflect the views of the private sector as they are based on surveys of entrepreneurs. Thus, what is being assessed is not the theoretical legal framework adopted by legislature but rather the actual conditions facing individuals. This is the main advantage of the subjective indicators used in this analysis, (i.e. indicators based on opinions either of country experts or of private sector participants); they tend to reflect the reality of institutional reform rather than the rules that exist on paper. In terms of country coverage, I use both regional and global data sets. The regional data sets cover only the transition economies of the FSU and Eastern Europe. The cross section data sets cover transition economies in Asia and Africa, which will also be included in the analysis. However, the focus of the paper is on the "traditional" transition economies.

It is also important to note what this paper does not do: it is not qualifying the political system. Although there exist indicators that gauge the degree of democracy or autocracy, or the extent of political and civil rights, these are not the issues addressed here. Political and civil right are mostly not associated with economic performance whereas institutional variables of the kind used here have been shown to be closely associated with investment and growth. ${ }^{4}$

\footnotetext{
${ }^{3}$ As emphasized for instance by North (1981).
}

${ }^{4}$ Mauro (1995), Knack and Keefer (1995) Brunetti and Weder (1998) study of large samples of countries and find that institutional performance impacts on investment and growth. Brunetti, Kisunko and Weder (1997) and Havrylyshyn, and van Rooden (2000) investigate transition economies and find a positive impact of institutions on FDI and growth (respectively). The results of the latter paper are consistent with the view that at first stabilization and good policy stimulate recovery, but sustained growth requires adequate pari passu development of institutions, which becomes more important over time.

${ }^{5}$ Another dimension that is not in the scope of this paper, but which could easily be addressed with a similar methodology are structural reforms, which include inter alia the degree of privatization, the degree to which the domestic financial system has been developed, the working of central banks etc. 
The paper is organized as follows. The first section describes the data and presents some comparisons within the group of transition economies. The second section compares transition economies to the rest of the world by running regressions in a large cross section. The third section presents result from mapping transition economies within a worldwide comparison of institutional performance into clusters. The fourth section concludes.

\section{A. Indicators of Institutional Performance and Differences Within Transition Countries}

The paper makes use of three data sets on institutional indicators two of which are themselves aggregations from several underlying data sets. The first data set is from Kaufmann, Kraay, and Zoido Lobaton (1999a). They calculate six aggregate indicators on a scale from -20 to +20 (with higher ratings indicating better performance) for the period $1997-98 .{ }^{6}$ Each indicator is based on aggregating information from a large number of underlying component indicators. For instance the aggregate indicators of "Rule of Law" is based on 28 component indicators which are in turn drawn from nine different sources. The advantage of this aggregation exercise is that it creates a comprehensive cross section: the total number of countries in this data set is 175 and it includes all transition economies. The main disadvantage is that noise may be introduced into each indicator by combining information from so many different sources, which explains why the standard errors of the estimate is quite large (see Kaufmann, Kraay, and Zoido Lobaton, 1999b). Their approach presupposes that all component indicators which are used to calculate the summary indicator are measures of the same underlying basic concept. However, when combining information form such a large variety of sources this assumption may easily be violated. Nevertheless, I use these indicators (in addition to others) because they are the most comprehensive governance indicators available. In the tables, all indicators from this source are labeled PP, which stands for poll of polls.

A second data set from Brunetti, Kisunko, and Weder (1998), is derived from a worldwide survey of private sector views in 73 countries conducted in preparation of the World Development Report 1997. This data covers a sample of 20 transition economies. The scale is from one to six, with higher ratings indicating better performance. The advantage of this survey data is that it provides detailed indicators for instance on issues such as judiciary enforcement or predictability of rules. In the tables, indicators from this source are labeled PSS, private sector survey.

A third source is Campos (2000), who aggregates indicators from various sources. This source provides time series data and thus permits an assessment of institutional progress in

\footnotetext{
${ }^{6}$ The indicators are called "Voice and Accountability," "Political Instability and Violence," "Government Effectiveness," "Regulatory Burden," "Rule of Law," and "Graft." In most of the paper I use five of the six variables, leaving aside the most political variable, "Political Instability and Violence." Each indicator is based on a combination of component indicators and the aggregation is performed with an unobserved components model (which expresses the observed data as a linear function of the unobserved common component of governance, plus a disturbance term capturing perception error and/or sampling variation in each indicator). See Kaufmann, Kraay, and Zoido Lobaton (1999a, p. 9).
} 
transition economies. It was compiled only for transition economies of the FSU and CEE, and therefore it does not provide a benchmark. The scale is from 0 to 10 with higher ratings indicating better performance.

All indicators data sets are described in Appendix Table 2.

Figure 1 gives a first impression of the differences between transition economies and their distance from industrialized countries in terms of institutional quality. It uses the overall institutional quality (IQ), an average of five PP indicators and subtracts the mean of the ratings of industrialized countries from each country rating. The results is one possible measure of the "Reform Gap" that is the distance that the country has to go in order to reach the level of institutional quality of the average industrialized country. The figure shows large differences. Hungary, Slovenia, and Poland have institutional quality ratings which are only five points below the average industrialized country (as noted above, the ratings range from -20 to +20 ) whereas the reform gap is massive in countries such as Turkmenistan, Tajikistan, or the Lao.

Figure 2 gives an impression of the changes in institutional quality over time. It presents means of bureaucratic quality (as calculated by Campos) for four groups of countries: the CIS, the Baltic's, the EU accession countries (which also include the Baltic's) and CE3, namely Hungary, Poland, and the Czech Republic. The main implication from this figure is that there are large differences between the transition countries. Furthermore, these differences already existed already a decade ago in 1989 and have stayed fairly constant over the last 10 years

Figure 1: The Reform Gap:

Deviation of PP Overall Average Institutional Quality (1997) from the Mean of Industrialized Countries

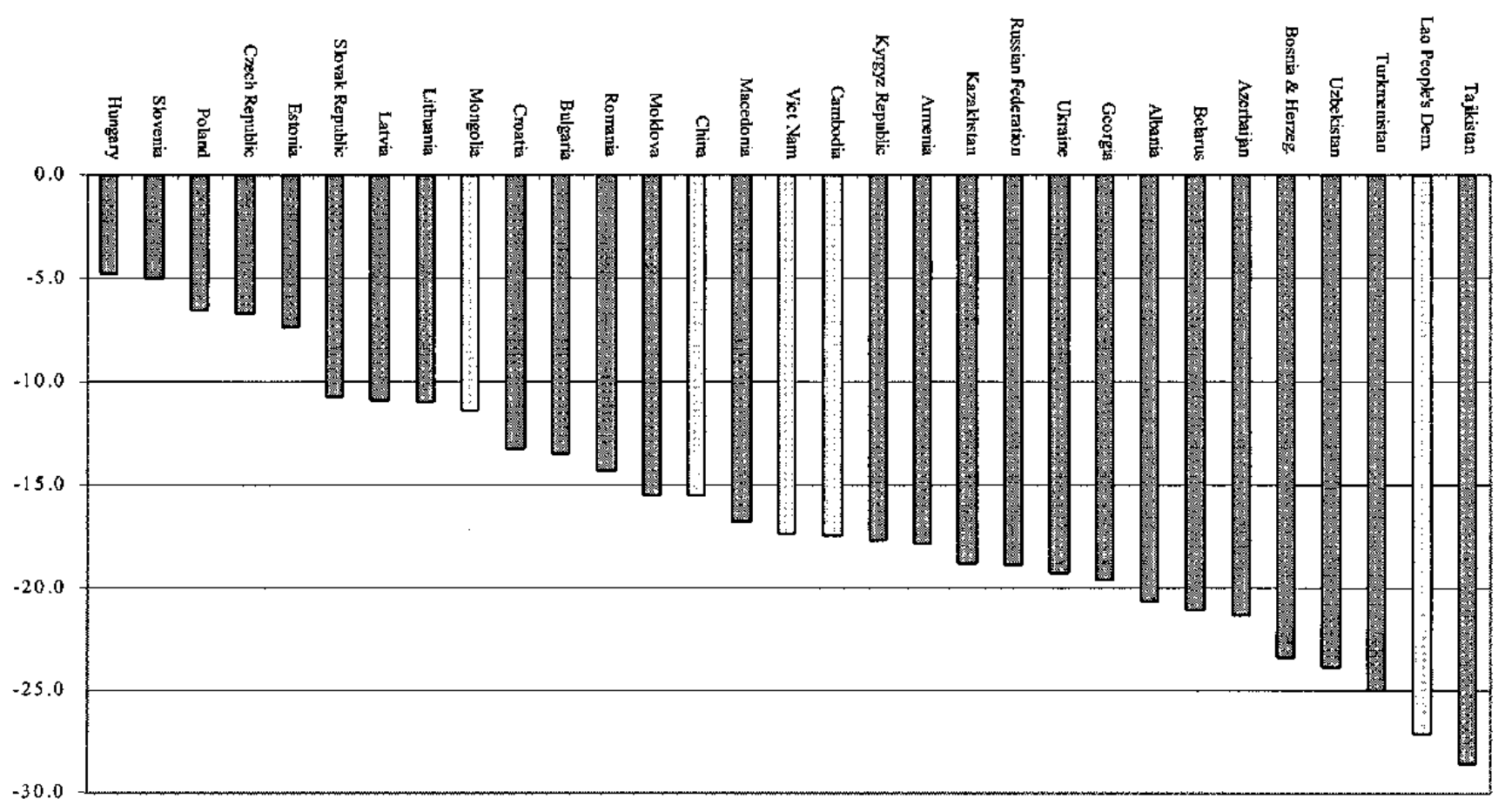


Figure 2: Time Series Evidence on Bureaucratic Performance by Country Groups Mean Bureaucratic Quality (NC), 1989-1997

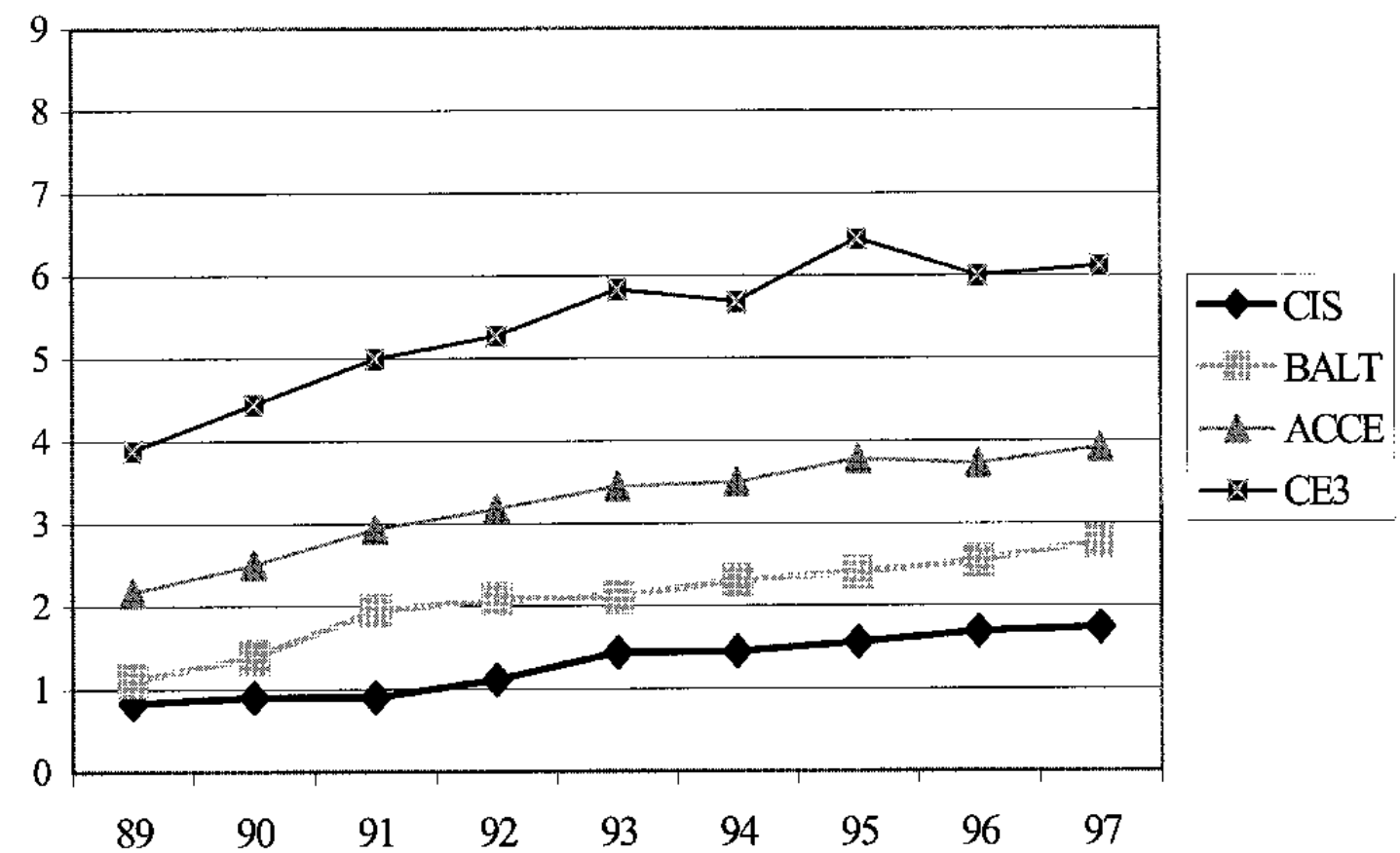

CIS Armenia, Azerbaijan, Belarus, Georgia, Kazakhstan, Kyrgyz, Moldova, Russia, Tajikistan, Turkmenistan, Ukraine, Uzbekistan

BALT Estonia, Lithuania, Latvia

ACCE Bulgaria, Czech Republic, Estonia, Hungary, Lithuania, Moldova, Poland, Romania, Slovakia, Slovenia

CE3 Czech Republic, Hungary, Poland

\section{B. Are Transition Economies Different from the Rest of the World? Results from Cross- Country Estimates of Institutional Conditions}

This section presents the results of cross-country estimates of institutional conditions. The aim is to test whether institutional conditions in transition economies are recognizably different from other countries with a similar per capita income. Following Gros and Suhrke (2000) initially I adopt a dummy variable approach, that is I estimate equations of the following type:

$$
\mathrm{IQ}_{\mathrm{i}}=\alpha+\beta \log \left(\mathrm{GDPpc}_{\mathrm{i}}\right)+\delta \text { TransDum }_{\mathrm{i}}+\phi \mathrm{OthDum}_{\mathrm{i}}+\varepsilon_{1}
$$

where IQ stands for various measures of institutional quality that are available for a cross-section of countries, (PP and PSS measures) GDPpc is GDP per capita, TransDum are dummies for groups of transition economies and Othdum stands for other regional country groups. I control for the level of income per capita because richer countries have a higher quality of institutions for a variety of reasons, and I want to control for differences in the stage of development. The first regression in Table 6 shows that GDPpc is positively associated with IQ and by itself 
explains about 60 percent of the cross country variation in IQ. TransDum are dummies for various groupings of transition economies: TRANSFSU\&CEE, (includes the FSU and the Eastern European countries), TRANSASIA and TRANSAFRICA. The definition of the transition dummies are shown in Appendix Table 1. GDPpc stands for income per capita in PPP terms in 1998 (from the Weo Data base). OthDum are other continental dummies, LATIN, AFRICA, EASIA and INDU (which stands for industrialized countries).

Table 1 shows the results of six indicators of institutional quality from PP. The first indicator, labeled "Overall Inst. Quality" is the average of the five following ones. The results show that the transition dummies are not significant. TRANSFSU\&CEE has a negative sign (implying lower institutional quality than in other countries with a similar income per capita) but it is not significant. (The same is true for AFRICA). TRANSASIA and TRANSAFRICA are not significant either. The INDU dummy is positive and the coefficient is large but it is not significant after controlling for differences in income. When the income variable is removed this indicator becomes highly significant. (AFRICA becomes significantly negative but all TRANS dummies remain insignificant at conventional levels). These first results suggest that institutional conditions in the transition economies are no longer different from the rest of the world.

The next regressions on the individual PP indicators (Rule of law, Graft, Regulatory Burden, Accountability and Government Effectiveness) mostly confirm this impression. The only dimension in which TRANSFSU\&CEE is recognizably different (and worse) from the rest of the world is graft. In the other dimensions the dummy is not significant after controlling for income per capita. ${ }^{7}$

Table 2 summarizes the results of 14 regressions. The aim is to test whether there are groups within the "classical" transition economies that are distinguishable from the rest of the world. After all, the fact that TRANSFSU\&CEE was not significant in the previous estimates could be related simply to large differences within this group that were documented in the previous section. In this table two dummies are considered, CIS and CEE (see Appendix Table 1 for countries in each dummy). The picture is now quite different from the one in Table 3: the CIS dummy is negative and significant in all but one regression. By contrast, the results on the CEE dummy are much more mixed: they are positive and significant in some cases, negative and significant in others and insignificantly different from zero in most cases. The CEE seem to have a higher overall institutional quality than countries with similar income levels and higher voice and accountability but seem to be less strong in terms of consultation and communication with the private sector and have more bureaucratic discretion than other countries in the same income class.

\footnotetext{
${ }^{7}$ Some interesting side results are that LATIN countries, as a group, have significantly less regulatory burden and are more accountability than predicted by their income, but have a significantly low ratings in terms of rule of law. INDUstrialized countries have more accountability even than predicted by their high income and EastASIAn countries are not special in any dimension except for Regulatory Burden, where they show significantly more.
} 
Table 1: Are Transition Economies Different? Cross-Country Evidence on Institutions and Transition Economies OLS Estimates, Various Dependent Variables, 1997

\begin{tabular}{|c|c|c|c|c|c|c|c|c|c|c|c|c|c|c|}
\hline \multirow[b]{3}{*}{ Independent Variable } & \multicolumn{12}{|c|}{ Dependent Variable } & \multirow{2}{*}{\multicolumn{2}{|c|}{ PP Gov. Effectivenss }} \\
\hline & \multicolumn{2}{|c|}{ PP Avg. Inst. Qual } & \multicolumn{2}{|c|}{ PP Avg. Inst. Qual } & \multirow{2}{*}{$\begin{array}{l}\text { PP Rule } \\
\text { coeff. }\end{array}$} & \multirow[b]{2}{*}{ t-Statistic } & \multirow{2}{*}{$\begin{array}{l}\text { PP Graft } \\
\text { coeff. }\end{array}$} & \multirow[b]{2}{*}{$\mathrm{t}$-Statistic } & \multicolumn{2}{|c|}{ PP Regul.Burden } & \multicolumn{2}{|c|}{ PP Accountab. } & & \\
\hline & coeff. & t-Statistic & coeff. & t-Statistic & & & & & coeff. & t-Statistic & coeff. & t-Statistic & coeff. & t-Statistic \\
\hline $\mathrm{C}$ & -5.83 & -9.84 & 5.25 & -4.67 & -6.03 & -5.21 & -6.15 & -5.86 & -4.02 & -2.88 & -4.17 & -3.05 & -6.70 & -5.18 \\
\hline GDPPP98 & 0.001 & 13.942 & 0.001 & 7.010 & 0.001 & 8.785 & 0.001 & 6.776 & 0.001 & 5.560 & 0.001 & 3.613 & 0.001 & 6.883 \\
\hline TRANSFSU\&CEE & & & -0.70 & -0.55 & -0.94 & -0.79 & -2.45 & -2.08 & -1.92 & -1.11 & 1.52 & 0.86 & -1.40 & -1.08 \\
\hline TRANSASIA & & & 0.02 & 0.01 & 0.92 & 0.43 & 1.83 & 1.57 & -1.20 & -0.35 & -4.02 & -1.02 & 4.12 & 2.94 \\
\hline TRANSAFRICA & & & 1.50 & 0.92 & 0.38 & 0.13 & -0.87 & -0.80 & 1.88 & 1.00 & 3.99 & 1.81 & 2.62 & 2.19 \\
\hline LATIN & & & 1.04 & 0.89 & -2.43 & -1.91 & -1.55 & -1.18 & 5.50 & 3.91 & 3.82 & 2.36 & 1.10 & 0.80 \\
\hline AFRICA & & & -1.41 & -1.10 & -1.05 & -0.71 & 0.00 & 0.00 & -1.00 & -0.62 & -2.35 & -1.44 & 0.22 & 0.15 \\
\hline INDU & & & 2.05 & 1.06 & 0.34 & 0.18 & 2.83 & 1.09 & 0.02 & 0.01 & 5.87 & 1.93 & 3.28 & 1.45 \\
\hline EASIA & & & -0.86 & -0.57 & -0.77 & -0.36 & -0.36 & -0.20 & 2.37 & 2.06 & -5.05 & -1.64 & 0.80 & 0.37 \\
\hline Adjusted R-squared & 0.62 & & 0.62 & & 0.67 & & 0.70 & & 0.41 & & 0.44 & & 0.65 & \\
\hline S.E. of regression & 4.97 & & 5.01 & & 5.28 & & 5.03 & & 5.97 & & 7.02 & & 5.19 & \\
\hline Numb. Countries & 160 & & 160 & & 154 & & 143 & & 154 & & 160 & & 144 & \\
\hline
\end{tabular}

Standard Errors are calculated using White correction. 
Table 2: FSU and CEE in Cross-Country Comparisons OLS Estimates, Various Dependent Variables, 1997

\begin{tabular}{|c|c|c|c|c|c|c|}
\hline \multirow[b]{2}{*}{ Dependent Variable } & \multirow[b]{2}{*}{$\mathrm{C}$} & \multirow[b]{2}{*}{ GDPPP98 } & \multicolumn{2}{|c|}{ Independent Variables } & \multirow[b]{2}{*}{ Adj. R2 } & \multirow[b]{2}{*}{ No. of Obs. } \\
\hline & & & CIS & CEE & & \\
\hline PP Average Institutional & -5.48 & 0.001 & -4.11 & 1.77 & 0.64 & 160 \\
\hline Quality & -8.54 & 13.520 & -3.64 & 1.74 & & \\
\hline \multirow[t]{2}{*}{ PP, Rule of Law } & -6.73 & 0.001 & -2.67 & 1.15 & 0.68 & 154 \\
\hline & -9.33 & 15.776 & -2.09 & 1.21 & & \\
\hline \multirow[t]{2}{*}{ PP, Low Graft } & -6.54 & 0.001 & -4.90 & -0.82 & 0.71 & 143 \\
\hline & -10.49 & 12.658 & -5.66 & -0.70 & & \\
\hline PP, Low Regulatory & -2.95 & 0.001 & -8.09 & 1.45 & 0.43 & 154 \\
\hline Burden & -3.62 & 9.715 & -4.90 & 1.20 & & \\
\hline PP, Accountability and & -4.57 & 0.001 & -3.68 & 5.14 & 0.40 & 160 \\
\hline Voice & -5.15 & 7.664 & -2.06 & 3.87 & & \\
\hline $\mathrm{PP}$, Government & -6.02 & 0.001 & -4.97 & -0.48 & 0.66 & 144 \\
\hline Effectiveness & -8.54 & 12.584 & -4.84 & -0.39 & & \\
\hline PSS, Predictability of & 3.12 & 0.000 & -0.45 & -0.19 & 0.37 & 73 \\
\hline Rule Changes & 47.12 & 5.980 & -2.92 & -0.89 & & \\
\hline PSS, Credibility of Gov. & 3.79 & 0.000 & -0.65 & -0.42 & 0.18 & 73 \\
\hline Announcements & 36.72 & 1.939 & -3.71 & -1.57 & & \\
\hline PSS, Information about & 2.86 & 0.000 & -0.22 & -0.45 & 0.38 & 73 \\
\hline Changes in Rules & 32.67 & 5.881 & -1.59 & -1.71 & & \\
\hline \multirow[t]{2}{*}{ PSS, Consultation } & 2.73 & 0.000 & -0.70 & -0.70 & 0.38 & 73 \\
\hline & 32.57 & 3.648 & -4.92 & -4.40 & & \\
\hline PSS, Property Rights & 2.10 & 0.000 & -0.42 & -0.23 & 0.30 & 73 \\
\hline Enforcement & 13.40 & 4.585 & -2.35 & -0.75 & & \\
\hline \multirow[t]{2}{*}{ PSS, Judiciary Reliability } & 2.42 & 0.000 & -0.35 & -0.17 & 0.44 & 73 \\
\hline & 19.49 & 5.960 & -2.16 & -1.11 & & \\
\hline PSS, Predictability of & 3.69 & 0.000 & -0.46 & -0.13 & 0.37 & 72 \\
\hline Bribes & 29.35 & 4.271 & -2.97 & -0.58 & & \\
\hline PSS, Freedom from & 3.02 & 0.000 & -0.30 & -0.29 & 0.32 & 72 \\
\hline Discretionary Bureaucrats & 37.03 & 4.070 & -3.10 & -1.86 & & \\
\hline
\end{tabular}

Note: T: Statistics below Coefficient, Standard Errors are calculated using White correction. 
Corruption has been such a prominent topic in transition economies that it is worth restating the results. Table 1 suggested that corruption is one dimension in which transition economies of the FSU and CEE have a markedly worse performance than other countries. Table 2 clarified that this pertains mostly to the CIS. This confirms what some observers have been claiming, namely that the problem of corruption is particularly serious in the CIS. Indeed some of the recent interest in corruption and some academic advances into this topic have been motivated by the experience of these countries. ${ }^{8}$

Table 3 has the same structure as Table 2, but focuses on testing whether EU accession countries are different. In all estimates with PP indicators, the EU accession dummy is significant and positive. For instance, the first estimate shows that in EU accession countries overall institutional quality is higher than predicted by their level of income. Moreover, a Wald test on the coefficient cannot reject the hypothesis that the coefficient of ACCE and of INDU are the same. The picture is a different when seen from the perspective of the private sector: the PPS indicators are negative for consultation, communication, predictability and credibility of government. The remaining PPS indicators (on the judiciary and the bureaucracy) are not significant.

Finally, as an additional check on the robustness of these results. I use an alternative to the dummy variable approach. I estimate the following equation:

$$
\mathrm{IQ}_{\mathrm{i}}=\alpha+\beta \log \left(\mathrm{GDPpc}_{\mathrm{i}}\right)
$$

excluding the transition economies for three income groups: (1) countries with (1998) GDP per capita below US\$3,000 (2) countries with (1998) GDP per capita between US\$3,000 and US $\$ 7,000$ and (3) countries with GDP per capita above US\$7,000. Using the estimates of the alpha and beta coefficients, thus obtained and the GDP per capita numbers of for the transition economies of the corresponding income groups, predicted values of institutional performance are derived. If the actual and the predicted values of the IQ measures for the transition economies are significantly different, one may conclude that these countries are still distinguishable from the rest of the world. The procedure differs somewhat from the dummy approach adopted above in that the latter assumes that the transition countries are sufficiently similar to the rest of the world to have common parameters alpha and beta and that information from these countries therefore can be exploited to estimate these parameters more efficiently.

The result of this exercise using PP is that predicted values and actual values of institutional quality in transition economies do differ significantly (the t-test for the equality of means between the two series yields $\mathrm{p}=0.02$ ) for the high and middle income countries. The low

${ }^{8}$ See e.g. Shleifer and Vishny (1995). For surveys of corruption and development see Bardhan (1997) or Tanzi (1994). Wolf and Gürgen (2000) give some actual examples of corruption and poor governance in transition 
income countries were excluded since institutional quality turned out not to be significantly related with income. ${ }^{9}$

Figure 3 shows the actual minus the predicted values of overall institutional quality for the middle and high income transition countries. By this measure Belarus, the Russian Federation and Turkmenistan are the largest under performers (their actual institutional quality is lower than predicted by their income and their membership in an income group). However, as mentioned above, for the group of transition economies overall actual institutional quality is well predicted by income and the two means are not significantly different. Thus, this additional exercise corroborates the finding of the dummy approach, namely that institutional quality in transition countries are no longer distinguishable from the rest of the world.

\section{Mapping Ex-Transition Economies into New Clusters}

Given the results of the previous sections it seems clear that the old transition label is no longer adequate. This last section maps the ex-transition economies into new groups by forming clusters of relatively homogenous institutional performers.

Table 4 presents the results of a of mapping countries into groups using cluster analysis, a technique that allows to identify homogeneous groups based on a large number of criteria. The results presented here were computed using six individual PP indicators (standardized for the level of income per capita). ${ }^{10}$ The algorithm used is K-Means cluster analysis. This algorithm works by assigning a country to the cluster with the smallest distance between the country and the center of the cluster. It thereby constructs groups of countries according to similarities (distances) between the sample elements measured over the six dimensional space.

\footnotetext{
${ }^{9}$ This many be an interesting results in itself since income and institutional quality are mostly thought to go hand in hand. However it does not apply for the poorest countries and this is robust for most measures of institutional quality and both, in samples including and excluding transition countries.

${ }^{10}$ In the table countries are presented in alphabetical order (on top the transition economies-in gray and below all other countries) since there is no particular ranking within each cluster. In addition to the "standard" PP indicators here I also included an indicator of political instability. The results are for the transition economies are sensitive to exclusions of this variable only in two cases: Turkmenistan and Uzbekistan are in the group of the poorest performers if we only consider the standard five PP indicators.
} 
Figure 3. Actual - Predicted Overall Institutional Quality

Predicted Performance is Based on Out of Sample Estimates for Groups of Income Levels

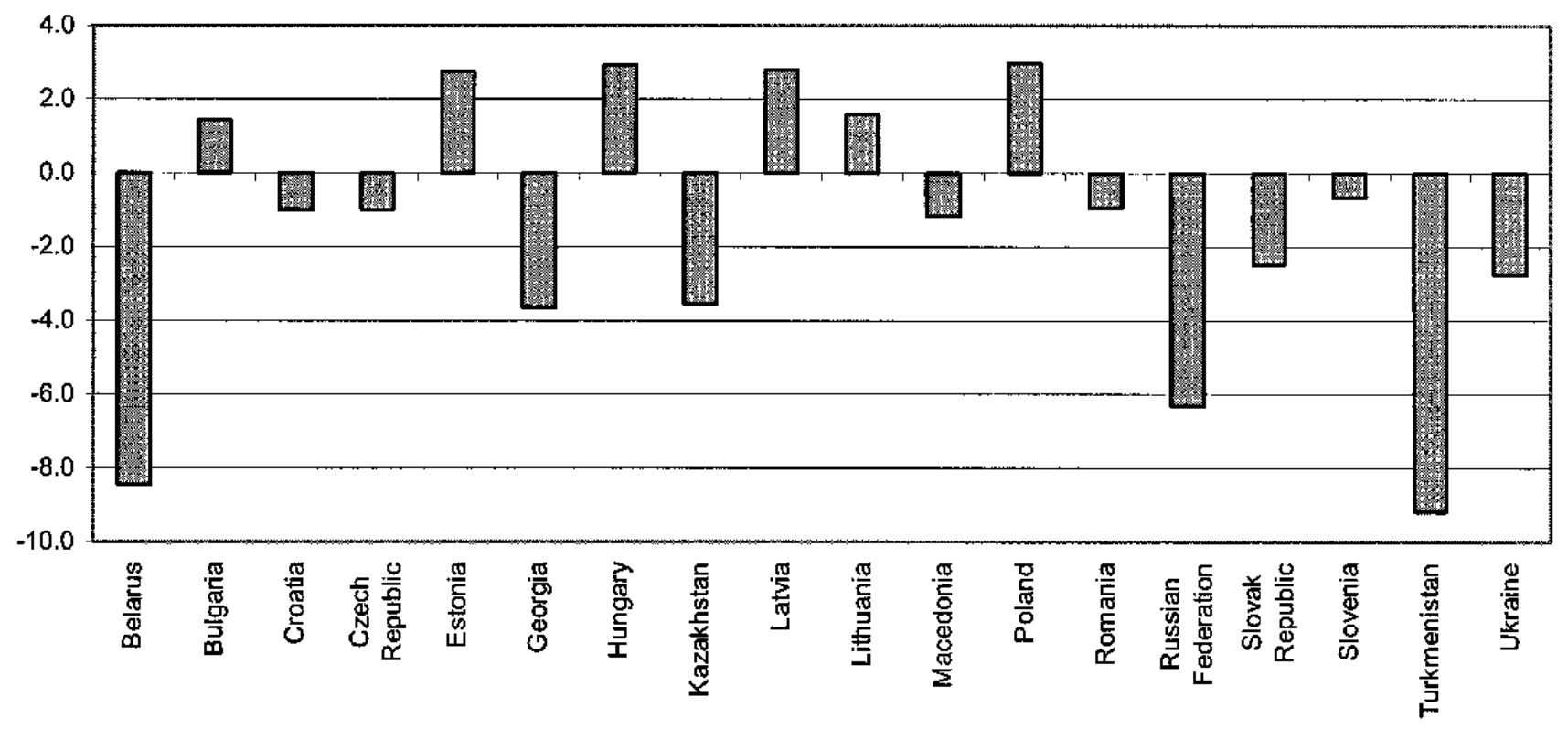


Table 3: Are Accession Countries Different? Cross Country Evidence OLS Estimates, Various Dependent Variables, 1997

\begin{tabular}{|c|c|c|c|c|c|c|c|c|}
\hline \multirow[b]{2}{*}{ Dependent Variable } & \multirow[b]{2}{*}{$\mathrm{C}$} & \multirow[b]{2}{*}{ GDPPP98 } & \multicolumn{3}{|c|}{ Independent Variables } & \multirow[b]{2}{*}{ LATIN } & \multirow[b]{2}{*}{ AFRICA } & \multirow[b]{2}{*}{$\begin{array}{l}\mathrm{R} 2 \\
\text { No. of Obs. }\end{array}$} \\
\hline & & & ACCE & INDU & EASIA & & & \\
\hline PP Avg. Institutional & -5.85 & 0.001 & 4.37 & 3.01 & -0.06 & 1.73 & -0.61 & 0.64 \\
\hline Quality & -6.58 & 7.518 & 4.50 & 1.63 & -0.04 & 1.66 & -0.52 & 160 \\
\hline \multirow[t]{2}{*}{ PP, Rule of Law } & -6.57 & 0.001 & 2.55 & 1.00 & -0.17 & -1.86 & -0.42 & 0.67 \\
\hline & -7.46 & 9.606 & 2.82 & 0.55 & -0.08 & -1.64 & -0.31 & 154 \\
\hline \multirow[t]{2}{*}{ PP, Low Graft } & -7.38 & 0.001 & 2.24 & 3.68 & 0.66 & -0.42 & 1.07 & 0.69 \\
\hline & -8.94 & 7.158 & 1.71 & 1.43 & 0.39 & -0.35 & 0.92 & 143 \\
\hline PP, Low Regulatory & -5.35 & 0.001 & 5.38 & 1.36 & 3.71 & 6.84 & 0.52 & 0.44 \\
\hline Burden & -4.72 & 6.360 & 4.58 & 0.82 & 3.47 & 5.34 & 0.35 & 154 \\
\hline PP, Accountability and & -4.62 & 0.001 & 8.64 & 7.15 & -4.13 & 4.47 & -1.50 & 0.47 \\
\hline Voice & -4.01 & 3.533 & 7.21 & 2.43 & -1.39 & 2.96 & -0.97 & 160 \\
\hline PP, Government & -7.13 & 0.001 & 2.12 & 4.06 & 1.43 & 1.62 & 1.02 & 0.65 \\
\hline Effectiveness & -7.39 & 7.335 & 1.53 & 1.83 & 0.67 & 1.34 & 0.77 & 144 \\
\hline PSS, Predictability of & 3.06 & 0.000 & -0.29 & 0.13 & 0.43 & 0.06 & -0.04 & 0.32 \\
\hline Rule Changes & 26.28 & 2.891 & -1.93 & 0.55 & 2.41 & 0.39 & -0.30 & 73 \\
\hline PSS, Credibility of Gov. & 3.51 & 0.000 & -0.52 & -0.29 & 0.36 & -0.25 & 0.39 & 0.2 \\
\hline Announcements & 22.71 & 2.397 & -2.35 & -0.86 & 0.80 & -1.39 & 2.01 & 73 \\
\hline PSS, Information about & 2.92 & 0.000 & -0.81 & -0.08 & 0.51 & 0.07 & -0.21 & 0.52 \\
\hline Changes in Rules & 26.93 & 3.443 & -5.36 & -0.27 & 2.10 & 0.41 & -1.50 & 73 \\
\hline \multirow[t]{2}{*}{ PSS, Consultation } & 2.48 & 0.000 & -0.61 & 0.02 & 0.53 & 0.38 & 0.09 & 0.32 \\
\hline & 18.03 & 2.045 & -4.22 & 0.06 & 1.50 & 2.08 & 0.56 & 73 \\
\hline PSS, Property Rights & 2.00 & 0.000 & -0.09 & -0.03 & 1.38 & -0.31 & 0.11 & 0.37 \\
\hline Enforcement & 10.42 & 2.645 & -0.31 & -0.06 & 3.36 & -1.01 & 0.42 & 73 \\
\hline \multirow[t]{2}{*}{ PSS, Judiciary Reliability } & 2.38 & 0.000 & 0.02 & 0.22 & 1.01 & -0.19 & 0.02 & 0.48 \\
\hline & 16.03 & 3.430 & 0.08 & 0.60 & 3.71 & -0.64 & 0.09 & 73 \\
\hline PSS, Predictability of & 3.63 & 0.000 & 0.13 & 0.40 & -0.12 & -0.11 & 0.00 & 0.32 \\
\hline Bribes & 21.33 & 1.748 & 0.50 & 0.76 & -0.21 & -0.58 & 0.02 & 72 \\
\hline PSS, Freedom from & 2.85 & 0.000 & -0.03 & -0.02 & 0.14 & 0.11 & 0.16 & 0.44 \\
\hline Discretionary Bureaucrats & 29.31 & 3.190 & -0.15 & -0.05 & 0.44 & 0.76 & 1.18 & 72 \\
\hline
\end{tabular}

Note: T: Statistics below Coefficient, Standard Errors are caclucated using White correction 


\section{Table 4: Results of K-Means Cluster Analysis, Clusters based on Six PP Indicators}

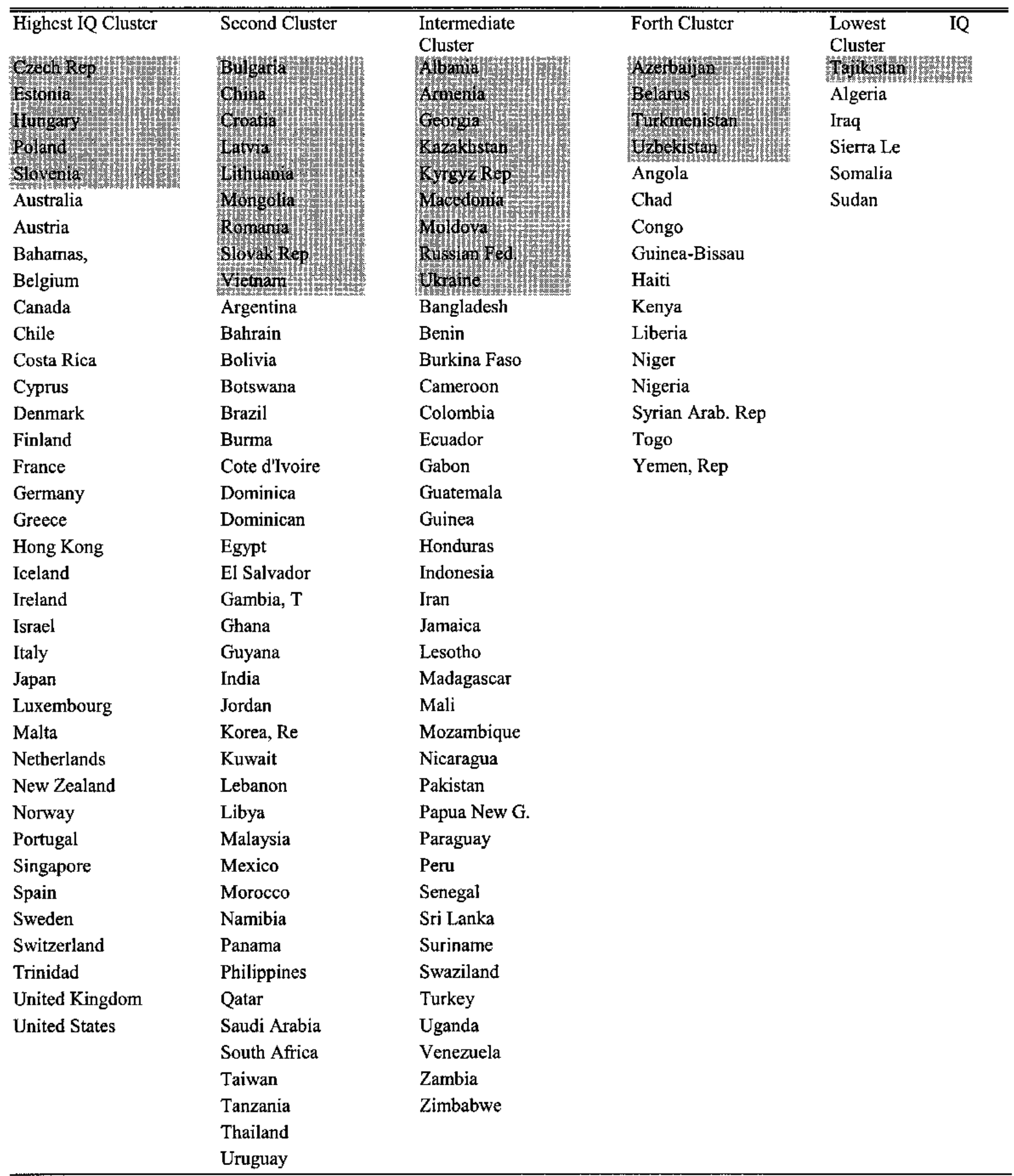

Notes: Countries are in alphabetical order (divided in transition and non-transition economies). An additional PP Indicator "Political violence" is included in this analysis. The results on transition economies is mostly unaffected if the analysis is conducted for five PP Indicators (without political violence); only Uzbekistan and Turkmenistan change cluster, membership: they then fall into the lowest cluster of institutional quality. 
Appendix Table 3 shows statistics of the data and results of the cluster analysis. The top panel presents descriptive statistics of the six dimensions of governance, the middle panel of Table 3 gives the cluster means for every dimension and the bottom panel shows the distribution of countries in five clusters. Appendix Figure 1 shows an "elbow" diagram, a diagnostic devise that helps determine the optimal number of clusters. ${ }^{11}$ It plots the fit of the classification against the number of clusters. The higher the number of clusters the better the fit of the classification (the lower the within-cluster variance and the higher the between-cluster variance). ${ }^{12}$ The fit improves visibly as the number of clusters reaches five and then improves only marginally with higher numbers of clusters. ${ }^{13}$ The continuation of Table 3 shows significance in cluster differences in all six dimensions based on an analysis of the variance of cluster means (within and between group variance).

The results from the cluster analysis confirm some earlier results: In other words, extransition economies are found in every cluster. Five of them now fall into the cluster with the highest mean performance along all institutional dimensions. Nine transition economies are found in the second and third clusters, respectively. Five (out of 16) transition economies are in the second last cluster and one (out of six) in the very last cluster.

The results emphasize that a group of ex-transition economies have "graduated" to the cluster of the highest institutional performers (after taking into account their level of development).${ }^{14}$ These are the Czech Republic, Estonia, Hungary, Poland, and Slovenia. In the second cluster we find the other two Baltic's and the other countries of the CEE, as well as some Asian transitions economies: China, Mongolia, and Vietnam come into the same cluster. The intermediate cluster contains most of the FSU countries with the exception of Azerbaijan, Belarus, Turkmenistan, and Uzbekistan, which belong to the low cluster. Again, we find Tajikistan in the bottom cluster.

Finally, Table 5 shows the results of the same cluster analysis exercise using the raw PP indicators, that is not controlling for the level of development. So far, in the paper I have preferred to evaluate institutional performance by taking into account the relative level of development, since clearly institutional and economic development go hand in hand. However, causality may be going in both directions and therefore, this last table gives an indication of how well former transition economies are doing in absolute terms. By this measure, none of the former transition economy falls in to the cluster of highest institutional quality. However, we still

\footnotetext{
${ }^{11}$ The number of clusters was determined using an explorative hierarchical cluster analysis.

${ }^{12}$ In other world that classification fit is best (and this criterion is zero) when the number of clusters is equal to the number of countries.
}

${ }^{13}$ An alternative classification, according to this criterion, would be one which considers only three clusters. But this would come at the cost more heterogeneity within each cluster.

${ }^{14}$ If the correction for the level of income is not made and instead the raw indicators are used we find all of these economies in the second cluster. 
find former transition economies in the other four clusters, with most EU accession candidates in the second highest quality cluster.

Table 5: Results of K-Means Cluster Analysis, Clusters based on Six PP Indicators (without controlling for differences in GDP per capita)

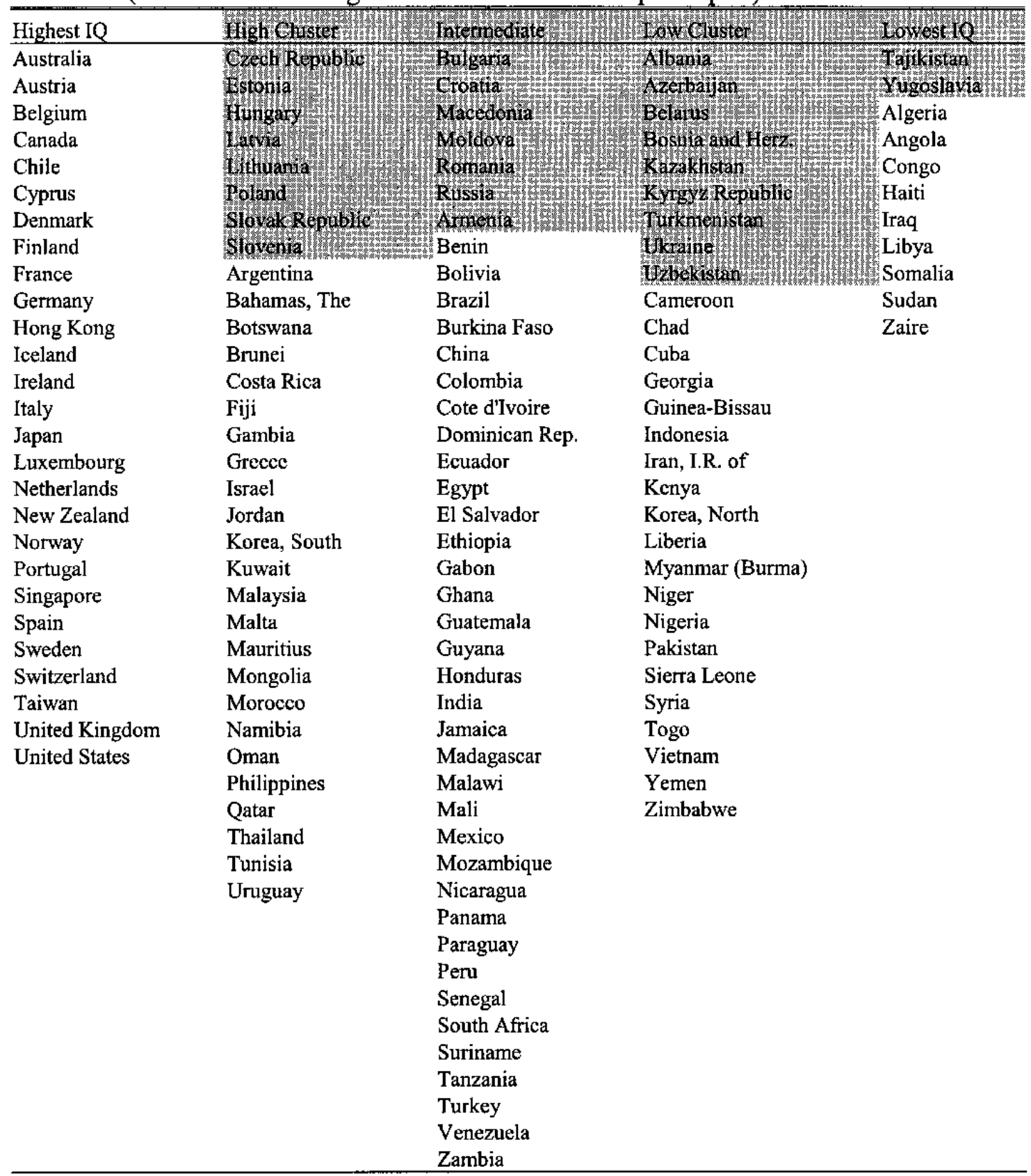




\section{Conclusions}

This paper has used governance indicators from different sources to explore the state of institutional conditions in transition economies and has obtained results that are quite consistent across indicators and sources. They show that transition economies are very diverse in terms of their institutional conditions but that transition economies as a group are no longer distinguishable from other economies. It follows that, at least as far as the institutional framework is concerned, the label "transition economies" is no longer warranted, since there is no such homogenous grouping. It should probably be replaced by a series of new labels since there are groupings of countries that are very similar among themselves and dissimilar from the others. For instance, the EU accession countries as a group have clearly better institutional conditions than the countries of the FSU. In fact, one finding of the paper is that institutional conditions of EU accession countries are no longer significantly different from those of industrialized countries. A formal cluster analysis confirms this by allocating five EU accession countries in the cluster of best institutional performers. 
Table 1. Countries Included in Transition Dummies and Country Coverage of the Three Main Data Sets, PSS, PP, EBRD

\begin{tabular}{|c|c|c|c|c|c|c|c|}
\hline CTRY & Country & DumFSU & DumCIS & DumCEE & $\mathrm{ACCE}$ & PSS & $\mathrm{PP}$ \\
\hline \multicolumn{8}{|c|}{ TRANSFSU\&CEE } \\
\hline ALB & Albania & $\mathrm{N}$ & $\mathrm{N}$ & $\mathrm{Y}$ & $\mathrm{N}$ & $\mathrm{Y}$ & $\mathrm{Y}$ \\
\hline ARM & Armenia & $\mathrm{Y}$ & $\mathrm{Y}$ & $N$ & $\mathrm{~N}$ & $\mathrm{Y}$ & $\mathrm{Y}$ \\
\hline $\mathrm{AZE}$ & Azerbaijan & $\mathrm{Y}$ & $\mathrm{Y}$ & $N$ & $\mathrm{~N}$ & $\mathrm{Y}$ & $\mathrm{Y}$ \\
\hline BLR & Belarus & $\mathrm{Y}$ & $\mathrm{Y}$ & $\mathrm{N}$ & $\mathrm{N}$ & $\mathrm{Y}$ & $\mathrm{Y}$ \\
\hline BIH & Bosnia and Herz & $\mathrm{N}$ & $\mathrm{N}$ & $\mathrm{Y}$ & $\mathrm{N}$ & $\mathrm{N}$ & $\mathrm{Y}$ \\
\hline BGR & Bulgaria & $\mathrm{N}$ & $\mathrm{N}$ & $\mathrm{Y}$ & $\mathrm{Y}$ & $\mathrm{Y}$ & $\mathrm{Y}$ \\
\hline HRV & Croatia & $\mathrm{N}$ & $\mathrm{N}$ & $\mathrm{Y}$ & $\mathrm{N}$ & $\mathrm{N}$ & $\mathrm{Y}$ \\
\hline $\mathrm{CZE}$ & Czech Republic & $\mathrm{N}$ & $\mathrm{N}$ & $\mathrm{Y}$ & $\mathrm{Y}$ & $\mathrm{Y}$ & $\mathrm{Y}$ \\
\hline EST & Estonia & $\mathrm{Y}$ & $\mathrm{N}$ & $\mathrm{N}$ & $\mathrm{Y}$ & $\mathrm{Y}$ & $\mathrm{Y}$ \\
\hline GEO & Georgia & $\mathrm{Y}$ & $\mathrm{Y}$ & $\mathrm{N}$ & $\mathrm{N}$ & $\mathrm{Y}$ & $\mathrm{Y}$ \\
\hline HUN & Hungary & $\mathrm{N}$ & $\mathrm{N}$ & $\mathrm{Y}$ & $\mathrm{Y}$ & $\mathrm{Y}$ & $\mathrm{Y}$ \\
\hline $\mathrm{KAZ}$ & Kazakhstan & $\mathrm{Y}$ & $\mathrm{Y}$ & $\mathrm{N}$ & $\mathrm{N}$ & $\mathrm{Y}$ & $\mathrm{Y}$ \\
\hline $\mathrm{KGZ}$ & Kyrgyz Republic & $\mathrm{Y}$ & $\mathrm{Y}$ & $\mathrm{N}$ & $\mathrm{N}$ & $\mathrm{Y}$ & $\mathrm{Y}$ \\
\hline LVA & Latvia & $\mathrm{Y}$ & $\mathrm{N}$ & $\mathrm{N}$ & $\mathrm{Y}$ & $\mathrm{Y}$ & $\mathrm{Y}$ \\
\hline LTU & Lithuania & $\mathrm{Y}$ & $\mathrm{N}$ & $\mathrm{N}$ & $\mathrm{Y}$ & $\mathrm{Y}$ & $\mathrm{Y}$ \\
\hline MKD & Macedonia & $\mathrm{N}$ & $\mathrm{N}$ & $\mathrm{Y}$ & $\mathrm{N}$ & $\mathrm{Y}$ & $\mathrm{Y}$ \\
\hline MDA & Moldova & $\mathrm{Y}$ & $\mathrm{Y}$ & $N$ & $\mathrm{~N}$ & $\mathrm{Y}$ & $Y$ \\
\hline POL & Poland & $\mathrm{N}$ & $\mathrm{N}$ & $\mathrm{Y}$ & $\mathrm{Y}$ & $\mathrm{Y}$ & $\mathrm{Y}$ \\
\hline ROM & Romania & $\mathrm{N}$ & $\mathrm{N}$ & $\mathrm{Y}$ & $\mathrm{Y}$ & $N$ & $\mathrm{Y}$ \\
\hline RUS & Russian Federation & $\mathrm{Y}$ & $\mathrm{Y}$ & $\mathrm{N}$ & $\mathrm{N}$ & $\mathrm{Y}$ & $\mathrm{Y}$ \\
\hline SVK & Slovak Republic & $\mathrm{N}$ & $\mathrm{N}$ & $\mathrm{Y}$ & $\mathrm{Y}$ & $\mathrm{Y}$ & $\mathrm{Y}$ \\
\hline SVN & Slovenia & $\mathrm{N}$ & $\mathrm{N}$ & $\mathrm{Y}$ & $\mathrm{Y}$ & $\mathrm{N}$ & $\mathrm{Y}$ \\
\hline TJK & Tajikistan & $\mathrm{Y}$ & $\mathrm{Y}$ & $\mathrm{N}$ & $\mathrm{N}$ & $\mathrm{N}$ & $\mathrm{Y}$ \\
\hline TKM & Turkmenistan & $\mathrm{Y}$ & $\mathrm{Y}$ & $\mathrm{N}$ & $\mathrm{N}$ & $\mathrm{N}$ & $\mathrm{Y}$ \\
\hline UKR & Ukraine & $\mathrm{Y}$ & $\mathrm{Y}$ & $\mathrm{N}$ & $\mathrm{N}$ & $\mathrm{Y}$ & $\mathrm{Y}$ \\
\hline UZB & Uzbekistan & $\mathrm{Y}$ & $\mathrm{Y}$ & $\mathrm{N}$ & $\mathrm{N}$ & $\mathrm{Y}$ & $\mathrm{Y}$ \\
\hline \multicolumn{8}{|c|}{ TRANSASIA } \\
\hline KHM & Cambodia & & & & & $\mathrm{N}$ & $\mathrm{Y}$ \\
\hline CHN & China & & & & & $\mathrm{N}$ & $\mathrm{Y}$ \\
\hline LAO & Lao Pcople's & & & & & $\mathrm{N}$ & $\mathrm{Y}$ \\
\hline MNG & Mongolia & & & & & $\mathrm{N}$ & $\mathrm{Y}$ \\
\hline VNM & Viet Nam & & & & & $\mathrm{N}$ & $\mathrm{Y}$ \\
\hline \multicolumn{8}{|c|}{ TRANSAFRICA } \\
\hline BEN & Benin & & & & & $\mathrm{Y}$ & $\mathrm{Y}$ \\
\hline $\mathrm{COG}$ & Congo & & & & & $\mathrm{Y}$ & $\mathrm{Y}$ \\
\hline ETH & Ethiopia & & & & & $\mathrm{N}$ & $\mathbf{Y}$ \\
\hline MDG & Madagascar & & & & & $\mathrm{Y}$ & $\mathrm{Y}$ \\
\hline $\mathrm{MOZ}$ & Mozambique & & & & & $\mathrm{Y}$ & $\mathrm{Y}$ \\
\hline TZA & Tanzania & & & & & $Y$ & $\mathrm{Y}$ \\
\hline
\end{tabular}


Table 2. Description of Indicators and Sources

\begin{tabular}{|c|c|c|c|c|}
\hline & Method & $\begin{array}{l}\text { Countries } \\
\text { Transition /Total }\end{array}$ & Timing & Description \\
\hline $\begin{array}{l}\text { PP Overall Institutional } \\
\text { Quality }\end{array}$ & Mean of first five ve PP Indicators & $26 / 173$ & $\begin{array}{l}\text { 1997, Indicators } \\
\text { from 1996-1998 }\end{array}$ & $\begin{array}{l}\text { Kaufmann, Kraay, } \\
\text { and Zoido-Lobaton (1999) }\end{array}$ \\
\hline PP, Rule of Law & $\begin{array}{l}\text { Poll of Polls: Aggregation of Indicators } \\
\text { Unobserved Components Model }\end{array}$ & $26 / 173$ & $\begin{array}{l}\text { 1997, Indicators } \\
\text { from 1996-1998 }\end{array}$ & $\begin{array}{l}\text { Kaufmann, Kraay, } \\
\text { and Zoido-Lobaton (1999) }\end{array}$ \\
\hline PP, Low Graft & $\begin{array}{l}\text { Poll of Polls: Aggregation of Indicators } \\
\text { Unobserved Components Model }\end{array}$ & $26 / 173$ & $\begin{array}{l}\text { 1997, Indicators } \\
\text { from 1996-1998 }\end{array}$ & $\begin{array}{l}\text { Kaufmann, Kraay, } \\
\text { and Zoido-Lobaton (1999) }\end{array}$ \\
\hline $\begin{array}{l}\text { PP, Low Regulatory } \\
\text { Burden }\end{array}$ & $\begin{array}{l}\text { Poll of Polls: Aggregation of Indicators } \\
\text { Unobserved Components Model }\end{array}$ & $26 / 173$ & $\begin{array}{l}\text { 1997, Indicators } \\
\text { from } 1996-1998\end{array}$ & $\begin{array}{l}\text { Kaufmann, Kraay, } \\
\text { and Zoido-Lobaton (1999) }\end{array}$ \\
\hline $\begin{array}{l}\text { PP, Accountability and } \\
\text { Voice }\end{array}$ & $\begin{array}{l}\text { Poll of Polls: Aggregation of Indicators } \\
\text { Unobserved Components Model }\end{array}$ & $26 / 173$ & $\begin{array}{l}\text { 1997, Indicators } \\
\text { from 1996-1998 }\end{array}$ & $\begin{array}{l}\text { Kaufmann, Kraay, } \\
\text { and Zoido-Lobaton (1999) }\end{array}$ \\
\hline $\begin{array}{l}\text { PP, Govemment } \\
\text { Effectiveness }\end{array}$ & $\begin{array}{l}\text { Poll of Polls: Aggregation of Indicators } \\
\text { Unobserved Components Model }\end{array}$ & $26 / 173$ & $\begin{array}{l}\text { 1997, Indicators } \\
\text { from 1996-1998 }\end{array}$ & $\begin{array}{l}\text { Kaufinann, Kraay, } \\
\text { and Zoido-Lobaton (1999) }\end{array}$ \\
\hline $\begin{array}{l}\text { PP, Political Instability and } \\
\text { Violence }\end{array}$ & $\begin{array}{l}\text { Poll of Polls: Aggregation of Indicators } \\
\text { Unobserved Components Model }\end{array}$ & $26 / 173$ & $\begin{array}{l}\text { 1997, Indicators } \\
\text { from } 1996-1998\end{array}$ & $\begin{array}{l}\text { Kaufmann, Kraay, } \\
\text { and Zoido-Lobaton (1999) }\end{array}$ \\
\hline $\begin{array}{l}\text { PSS, Predictability of } \\
\text { Rule Changes }\end{array}$ & $\begin{array}{l}\text { Private Sector Survey in } \\
\text { each country }\end{array}$ & $26 / 173$ & 1997 & $\begin{array}{l}\text { Brunetti, Kisunko } \\
\text { and Weder (1998) }\end{array}$ \\
\hline $\begin{array}{l}\text { PSS, Credibility of Gov. } \\
\text { Announcements }\end{array}$ & $\begin{array}{l}\text { Private Sector Survey in } \\
\text { each country }\end{array}$ & $20 / 73$ & 1997 & $\begin{array}{l}\text { Brunetti, Kisunko } \\
\text { and Weder (1998) }\end{array}$ \\
\hline
\end{tabular}


Table 2 (continued). Description of Indicators and Sources

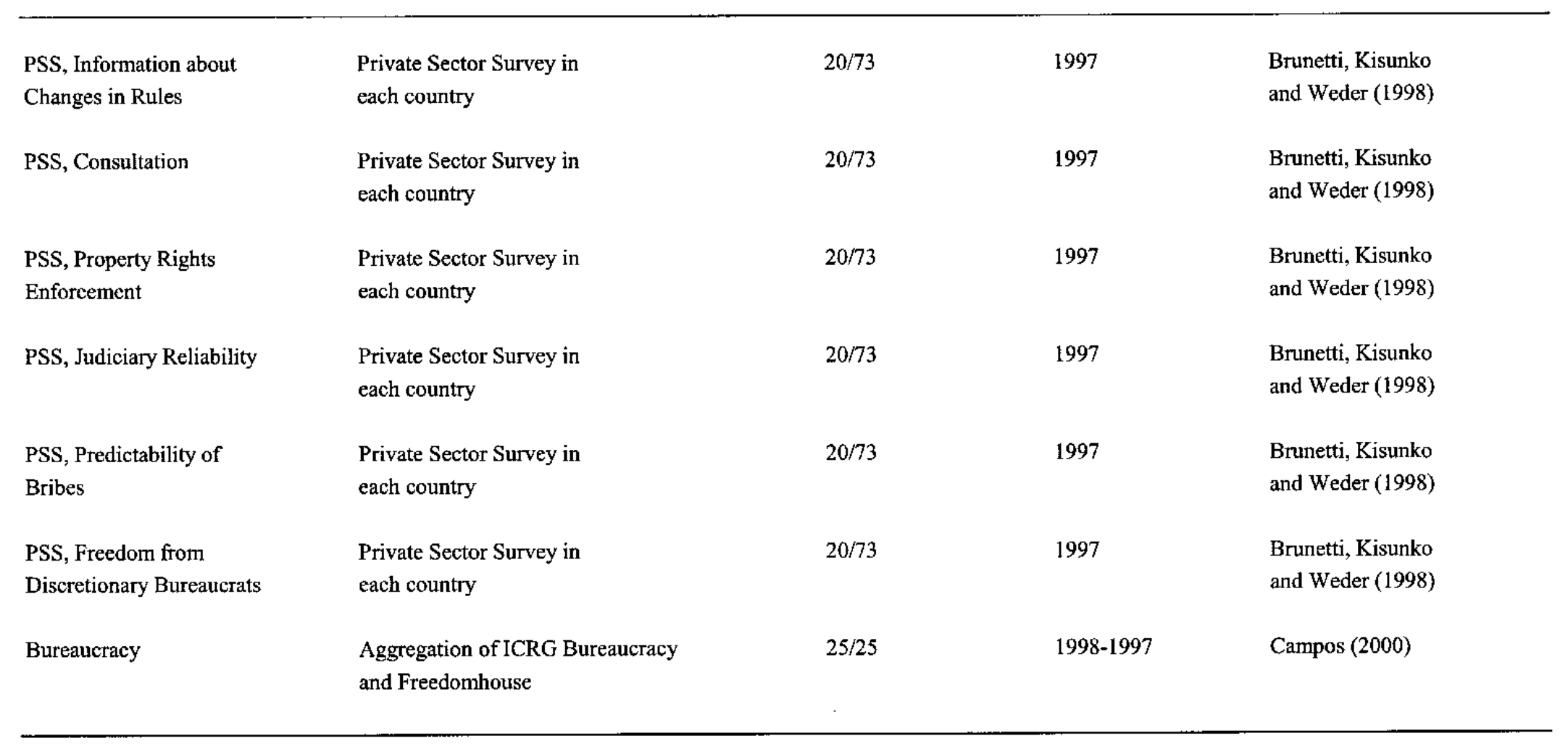


Table 3. Statistics on Results Cluster Analysis

\begin{tabular}{|c|c|c|c|c|c|}
\hline Descriptive Statistics & No & Minimum & Maximum & Mean & Std. Dev. \\
\hline PP Rule of Law & 165 & -239.09 & 195.79 & -8.45 & 102.94 \\
\hline PP Low GRAFT & 154 & -229.84 & 211.43 & -7.40 & 98.12 \\
\hline PP Government Effectiveness & 155 & -247.37 & 203.79 & -6.84 & 96.67 \\
\hline PP Low Regulatory Burden & 165 & -397.15 & 154.66 & -0.30 & 92.07 \\
\hline PP Accountability and voice & 171 & -268.95 & 166.14 & -0.07 & 106.87 \\
\hline $\begin{array}{l}\text { PP Low Political Instability } \\
\text { and Violence }\end{array}$ & 154 & -286.47 & 173.72 & -9.20 & 106.12 \\
\hline Valid N (listwise) & 154 & & & & \\
\hline Final Cluster Centers & $\begin{array}{l}\text { Highest } \\
\text { Cluster }\end{array}$ & $\begin{array}{l}\text { High } \\
\text { Cluster }\end{array}$ & $\begin{array}{l}\text { Intermediate } \\
\text { Cluster }\end{array}$ & $\begin{array}{l}\text { Low } \\
\text { Cluster }\end{array}$ & Lowest IQ \\
\hline PP Voice and Accountability & 128.40 & -1.06 & -24.51 & -120.77 & -219.88 \\
\hline PP Political Instability and Violen & 104.41 & 22.88 & -75.71 & -126.20 & -262.04 \\
\hline PP Government Effectiveness & 117.26 & 1.14 & -60.06 & -126.59 & -174.24 \\
\hline PP Regulatory Burden & 85.39 & 26.76 & -9.13 & -126.14 & -228.88 \\
\hline PP Rule of Law & 123.73 & 16.23 & -69.92 & -143.08 & -184.14 \\
\hline PP GRAFT & 129.47 & -11.14 & -74.75 & -107.57 & -124.39 \\
\hline Mean & 114.78 & 9.14 & -52.35 & -125.06 & -198.93 \\
\hline \multicolumn{3}{|l|}{ Number of Countries in each Cluster } & \multicolumn{3}{|c|}{ Transition economies in each Cluster } \\
\hline Highest & 38 & & 5 & & \\
\hline High & 54 & & 9 & & \\
\hline Intermediate & 40 & & 9 & & \\
\hline Low & 16 & & 5 & & \\
\hline Lowest & 6 & & 1 & & \\
\hline
\end{tabular}


Figure 1: Goodness of Classification and Number of Clusters

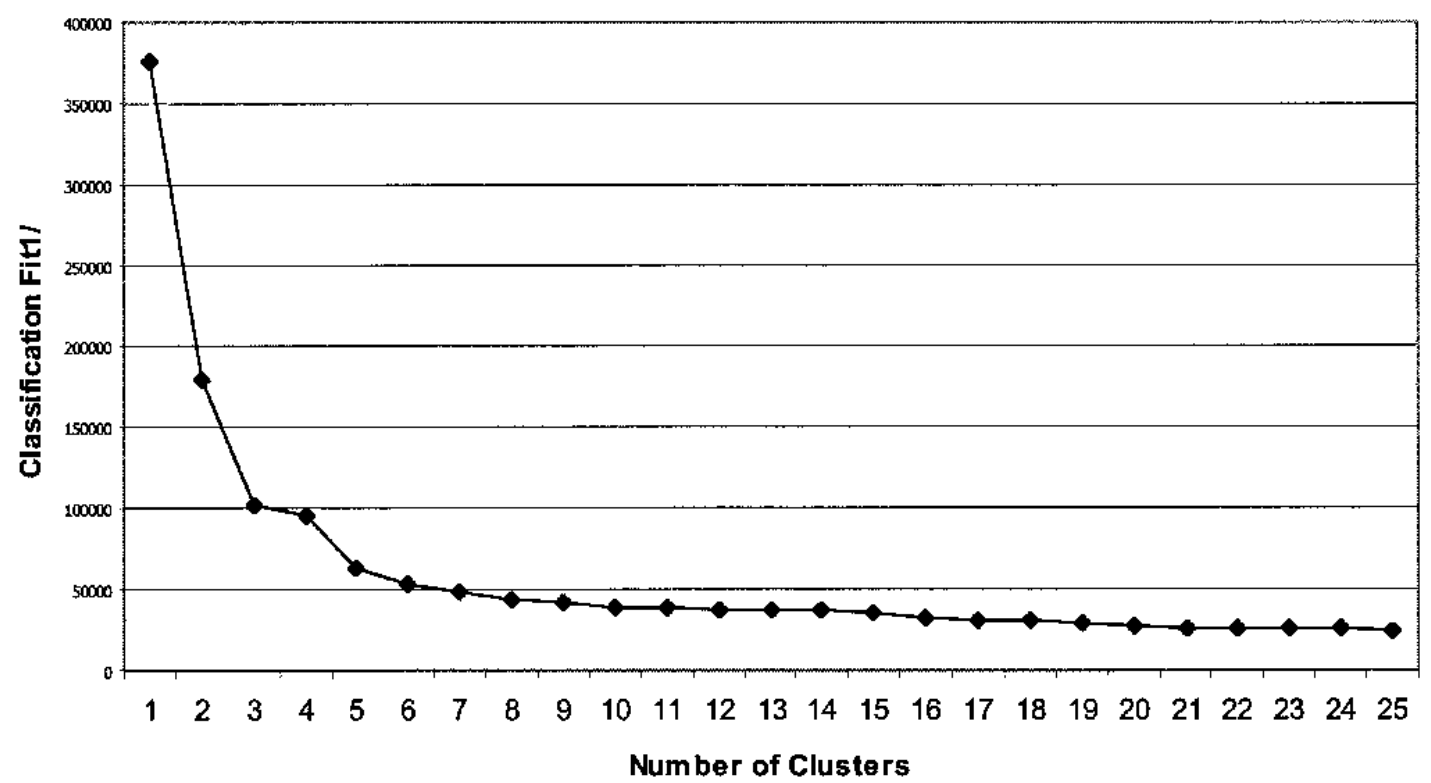

1/ Lower numbers indicate a better fit of classification (variance of characteristics within clusters and higher variance between clusters), based on hierarchical cluster analysis using the "between group linkage" Method. 


\section{REFERENCES}

Bardhan, Pranab,1997, "Corruption and Development," Journal of Economic Literature 25, pp. 1320-1346.

Berg, Andrew, Eduardo Borensztein, Ratna, Sahay and Jeromin Zettelmeyer, 1999, "The Evolution of Output in Transition Economies-Explaining the Differences," IMF Working Paper WP/99/73.

Brunetti, Aymo, Gregory Kisunko and Beatrice Weder, 1998, "Credibility of Rules and Economic Growth: Evidence from a Worldwide Survey of the Private Sector," 1998, World Bank Economic Review 12 (3), pp. 353-384.

Brunetti, Aymo, Gregory Kisunko, Beatrice Weder, 1997, "Institutions in Transition: Reliability of Rules and Economic Performance in Former Socialist Countries," World Bank Policy Research Working Paper No. 1809 , Washington DC: The World Bank.

Campos, Nauro, 2000, “Context is Everything," World Bank Policy Research Paper No. 2269.

European Bank for Reconstruction and Development, Transition Report, various issues.

Fischer, Stanley; Sahay, Ratna, 2000, "The Transition Economies After Ten Years," IMF Working Paper WP/00/30.

Gros, Daniel and Marc Suhrke, 2000, “Ten Years After: What is special about transition countries?" Paper presented at the Meetings of the American Economic Association, January 2000, in Boston.

Havrylyshyn, Oleh; van Rooden, Ron, 2000 "Institutions Matter in Transition, but so do Policies," IMF Working Paper WP/00/70.

Kaufmann Daniel, Aart Kraay and Paolo Zoido Lobaton, 1999a, "Governance Matters," The World Bank, at www.worldbank.org/wbi/governance/wp.htm.

Kaufmann Daniel, Aart Kraay and Paolo Zoido Lobaton, 1999b, "Aggregating Governance Indicators," The World Bank, at www.worldbank.org/wbi/governance/wp.htm.

Knack, Stephen and Philip Keefer, 1995, "Institutions and Economic Performance: CrossCountry Tests Using Alternative Institutional Measures," Economics and Politics 7, pp. 207-227.

La Porta, Rafael, Florencio Lopez-de-Silanes, Andrei Shleifer and Robert Vishny, 1998, "The Quality of Government," NBER Working Paper No. 6727, Cambridge MA: National Bureau of Economic Research.

Mauro Paolo, 1995, "Corruption and Growth," Quarterly Journal of Economics, 110(3) pp. 681712. 
North Douglass, 1981, Structure and Change in Economic History, New York: WW Norton.

Shleifer, Andrei and Robert Vishny, 1993, "Corruption," Quarterly Journal of Economics 108, pp. 599-617.

Tanzi, Vito, 1994, "Corruption, Governmental Activities and Markets," IMF Working Paper 94/99, Washington DC: International Monetary Fund.

Wolf, Thomas A. and Emine Gurgen, 2000, "Improving Governance and Fighting Corruption in the Baltic and the CIS Countries-The Role of the IMF," IMF Working Paper WP $/ 00 / 1$.

Wyplosz, Charles, 1999, "Ten Years of Transformation: Macroeconomic Lessons," Paper prepared for the World Bank Annual Bank Conference on Development Economics to be held in Washington on April 28-30, 1999. 